\title{
Recent growth of scientific journals published in India: Some publishing and citation-related characteristics
}

\author{
Keshra Sangwal* \\ Department of Applied Physics, Lublin University of Technology, ul. Nadbystrzycka, Lublin, Poland
}

\begin{abstract}
Using bibliometric data collected from journal citation reports (JCRs) covering the period 2008-2011, trends of the growth of scientific journals published in India, self-citation characteristics of their 2-year impact factors (IF2s) with and without self-citations and the relationship between their 2- and 5-year impact factors (IF5) are examined. The main findings of the study are that: (1) A majority of the top Indian journals belong to medical and medicinal sciences and are published by dominating publishers like MedKnow, Indian Academy of Sciences, National Institute of Science Communication and Information Resources (NISCAIR), and Indian Council of Medical Research (ICMR), whereas most of the bottom journals were published by scientific societies, associations, centers and other individual publishers, (2) Many of the journals were included in the JCR indexing system only recently but their ranking in the IF2 order strongly depends on the publication duration, (3) With their increasing publication duration, the values of IF2 and IF5 of the top journals increase, whereas those of the bottom journals decrease, (4) the frequency $f_{\mathrm{P}}=P / N$ of distribution of self-citation octiles $P=\mathrm{IF} 2{ }_{\mathrm{nsc}} / \mathrm{IF} 2$ and the frequence $f_{\mathrm{F}}=F / N$ of IF2 octiles $F$ for different years, where IF2 ${ }_{\text {nsc }}$ is the 2-year impact factor of a journal without self-citations and $N$ is the number of journals with IF2 in a given year, follow exponential dependence, and (5) IF5 $>$ IF2 for most of the journals but the proportion of journals where IF5 > IF2 varies enormously in different years.
\end{abstract}

Keywords: Impact factors, journal categories, journal self-citations

\section{INTRODUCTION}

Different aspects of the scientific publication behavior of researchers publishing in various national and international journals have been studied and differences between the citations of papers in English and nonEnglish languages on a global level have been recognized. Several studies have shown that citations per paper of nonEnglish journals are lower than those of English journals. ${ }^{[1-7]}$ Sangwal ${ }^{[6]}$ reported that: (1) the citability of papers published by physics, chemistry, and technical sciences professors in Poland decreases with increasing fraction of the papers in

*Address for correspondence:

E-mail: k.sangwal@pollub.pl

\begin{tabular}{|l|l|}
\hline \multicolumn{2}{|c|}{ Access this article online } \\
\hline Quick Response Code: & Website: \\
\hline & www.jscires.org \\
\cline { 2 - 3 } & \\
\cline { 2 - 2 } & DOI: \\
\hline
\end{tabular}

J Scientometric Res. | Jan-Apr 2013 | Vol 2 | Issue 1 volumes/issues of journals as proceedings of conferences and in nonEnglish language journals and (2) technical sciences professors have a higher tendency of publishing papers in proceedings of conferences than physics and chemistry professors.

The scientific impact of journals is traditionally measured in terms of their impact factors calculated from the total number of citations, including self-citations, received by the papers published in them and the ranking of a journal in its scientific discipline is determined by the journal impact factor. These impact factors of journals are usually used by research funding agencies as an evaluation measure of scientific performance of individual researchers, faculties, and institutes. In fact, adoption of impact factors of journals as a measure of scientific performance has resulted in an omnipresent pressure on editors to improve the impact factors of their journals and on authors to publish in journals with high impact factors. Since the impact factors of journals undergo changes from year to year, it is interesting to examine the factors that lead to changes in the impact factors. 
Mueller et al. ${ }^{[4]}$ found that impact factor of journals is closely related to the language than with the country of their origin. From an analysis of the citation data of journals published in nine different countries, Sangwal ${ }^{[8]}$ found that English-language journals, as a rule, have higher impact factors than nonEnglish-language journals. Although self-citations of journals are included in the calculation of their impact factors, no particular attention has been paid so far to analyze the distribution of self-citations of journals published in individual countries in relation to their impact factors. The aim of the present study is to examine the trends of the growth of scientific journals published in India, self-citation characteristics of their 2-year impact factors (IF2s) with and without self-citations and the relationship between their 2 - and 5 -year impact factors (IF5) using bibliometric data collected from Journal Citation Reports (JCRs) covering the period 2008-2011.

\section{DATA FOR ANALYSIS}

We used JCR (Science Edition) for the years 2008-2011 of Thomson Reuters' ISI Web of Knowledge database to collect appropriate bibliometric data about the journals published in India, their publishers, IF2s with journal selfcites, IF2s without journal self-cites (IF2 $\left.{ }_{\text {nsc }}\right)$, IF5s, journal categories (Q1-Q4) based on quartiles of categories, and journal self-citations. Some basic information about the journals collected from the JCR databases is given in Tables 1-3. All Indian journals included in the JCR lists are English-language journals. It should be noted that in Table 1 the categories of journals in a scientific field are listed in the decreasing order of IF2 and the corresponding publishers appear successively in that order. The abbreviations used for different publishers are explained in Table 2.

Here it is worthwhile to recall the procedure used in the JCR databases to calculate IF2 and IF5, respectively, and to assign a given journal to the category $\mathrm{Q}$ in a particular scientific research discipline, usually referred to as "subject category." Denoting the reference year by $Y$, IF2 and IF5 of a journal are defined as follows:

- IF2 $(Y)=$ total number of citations to papers published in the previous 2 years $(Y-2)$ and $(Y-1)$ divided by the number of papers published in the previous 2 years $(Y-1)$ and $(Y-2)$;

- $\operatorname{IF5}(Y)=$ total number of citations to papers published in the previous 5 years from $(Y-5)$ to $(Y-1)$ divided by the number of papers published in the previous 5 years from $(Y-5)$ to $(Y-1)$.
Table 1: Scientific fields of journals published in India, journal categories and their publishers*

\begin{tabular}{|c|c|c|c|}
\hline Scientific field & Year & Category & Publisher \\
\hline \multirow{4}{*}{$\begin{array}{l}\text { Agriculture, dairy, } \\
\text { and animal sciences }\end{array}$} & 2008 & Q4, Q4 & ICAR, other \\
\hline & 2009 & Q3, Q4, Q4 & assoc, other, ICAR \\
\hline & 2010 & $\begin{array}{l}\text { Q4, Q4, } \\
\text { Q4, Q4 }\end{array}$ & $\begin{array}{l}\text { other, assoc, } \\
\text { ICAR, center }\end{array}$ \\
\hline & 2011 & $\begin{array}{l}\text { Q3, Q4, } \\
\text { Q4, Q4 }\end{array}$ & $\begin{array}{l}\text { T and } F \text {, assoc, } \\
\text { ICAR, center }\end{array}$ \\
\hline \multirow{4}{*}{$\begin{array}{l}\text { Agriculture, } \\
\text { multidisciplinary }\end{array}$} & 2008 & Q4 & ICAR \\
\hline & 2009 & Q4, Q4 & ICAR, other \\
\hline & 2010 & Q4, Q4 & ICAR, other \\
\hline & 2011 & Q4, Q4 & ICAR, other \\
\hline \multirow[t]{4}{*}{ Agronomy } & 2008 & Q4 & other \\
\hline & 2009 & Q3, Q4 & other, assoc \\
\hline & 2010 & $\begin{array}{l}\text { Q3, Q4, Q4, } \\
\text { Q4, Q4 }\end{array}$ & $\begin{array}{l}\text { other, assoc, } \\
\text { center, soc, center }\end{array}$ \\
\hline & 2011 & $\begin{array}{l}\text { Q3, Q4, Q4, } \\
\text { Q4, Q4 }\end{array}$ & $\begin{array}{l}\text { other, soc, assoc, } \\
\text { center, center }\end{array}$ \\
\hline \multirow{2}{*}{$\begin{array}{l}\text { Anatomy and } \\
\text { morphology }\end{array}$} & 2010 & Q4 & soc \\
\hline & 2011 & Q4 & soc \\
\hline \multirow{4}{*}{$\begin{array}{l}\text { Astronomy and } \\
\text { astrophysics }\end{array}$} & 2008 & Q4 & Springer \\
\hline & 2009 & Q4, Q4 & IAS, soc \\
\hline & 2010 & Q2, Q4 & soc, IAS \\
\hline & 2011 & Q2, Q3 & SOC, IAS \\
\hline \multirow{4}{*}{$\begin{array}{l}\text { Biochemistry and } \\
\text { molecular biology }\end{array}$} & 2008 & Q4, Q4 & NISCAIR, SOC \\
\hline & 2009 & Q4, Q4, Q4 & $\begin{array}{l}\text { NISCAIR, Soc, } \\
\text { other }\end{array}$ \\
\hline & 2010 & Q4, Q4 & $\begin{array}{l}\text { NISCAIR, Springer } \\
\text { India }\end{array}$ \\
\hline & 2011 & Q4, Q4 & $\begin{array}{l}\text { NISCAIR, Springer } \\
\text { India }\end{array}$ \\
\hline \multirow[t]{4}{*}{ Biology } & 2008 & Q2, Q4 & Springer, NISCAIR \\
\hline & 2009 & Q2, Q4 & IAS, NISCAIR \\
\hline & 2010 & Q2, Q3, Q4 & $\begin{array}{l}\text { IAS, NISCAIR, } \\
\text { NASI }\end{array}$ \\
\hline & 2011 & Q2, Q3, Q4 & $\begin{array}{l}\text { IAS, NISCAIR, } \\
\text { NASI }\end{array}$ \\
\hline \multirow[t]{4}{*}{ Biophysics } & 2008 & Q4 & NISCAIR \\
\hline & 2009 & Q4 & NISCAIR \\
\hline & 2010 & Q4 & NISCAIR \\
\hline & 2011 & Q4 & NISCAIR \\
\hline \multirow{2}{*}{$\begin{array}{l}\text { Biotechnology and } \\
\text { applied microbiology }\end{array}$} & 2010 & Q4, Q4 & Springer, NISCAIR \\
\hline & 2011 & $\begin{array}{l}\text { Q4, Q4, } \\
\text { Q4, Q4 }\end{array}$ & $\begin{array}{l}\text { NISCAIR, Springer } \\
\text { India, other, other }\end{array}$ \\
\hline \multirow{2}{*}{$\begin{array}{l}\text { Cardiology and } \\
\text { cardiovascular } \\
\text { system }\end{array}$} & 2010 & Q4 & MedKnow \\
\hline & 2011 & Q3 & soc \\
\hline \multirow[t]{4}{*}{ Chemistry, applied } & 2008 & Q4 & NISCAIR \\
\hline & 2009 & Q4 & NISCAIR \\
\hline & 2010 & Q4 & NISCAIR \\
\hline & 2011 & Q4 & NISCAIR \\
\hline \multirow{2}{*}{$\begin{array}{l}\text { Chemistry, } \\
\text { medicinal }\end{array}$} & 2010 & Q4 & other \\
\hline & 2011 & Q4 & other \\
\hline \multirow[t]{2}{*}{$\begin{array}{l}\text { Chemistry, } \\
\text { multidisciplinary }\end{array}$} & 2008 & $\begin{array}{l}\text { Q3, Q3, } \\
\text { Q4, Q4 }\end{array}$ & $\begin{array}{l}\text { Springer, } \\
\text { NISCAIR, SPI, } \\
\text { other }\end{array}$ \\
\hline & 2009 & $\begin{array}{l}\text { Q3, Q3, Q4, } \\
\text { Q4, Q4 }\end{array}$ & $\begin{array}{l}\text { IAS, NISCAIR, } \\
\text { SPI, other, other }\end{array}$ \\
\hline
\end{tabular}

Contd... 
Table 1: Contd...

\begin{tabular}{|c|c|c|c|}
\hline Scientific field & Year & Category & Publisher \\
\hline & 2010 & $\begin{array}{l}\text { Q3, Q3, Q3, } \\
\text { Q4, Q4, } \\
\text { Q4 }\end{array}$ & $\begin{array}{l}\text { IAS, NISCAIR, } \\
\text { other, SPI, other, } \\
\text { other }\end{array}$ \\
\hline & 2011 & $\begin{array}{l}\text { Q3, Q3, } \\
\text { Q4, Q4 }\end{array}$ & $\begin{array}{l}\text { IAS, NISCAIR, } \\
\text { other, other }\end{array}$ \\
\hline \multirow[t]{4}{*}{ Chemistry, organic } & 2008 & Q4, Q4 & NISCAIR, other \\
\hline & 2009 & Q4, Q4 & NISCAIR, other \\
\hline & 2010 & Q4, Q4 & NISCAIR, other \\
\hline & 2011 & Q4, Q4 & NISCAIR, other \\
\hline \multirow[t]{2}{*}{ Clinical neurology } & 2010 & Q4 & MedKnow \\
\hline & 2011 & Q4 & MedKnow \\
\hline \multirow[t]{3}{*}{ Dermatology } & 2009 & Q4 & MedKnow \\
\hline & 2010 & Q4 & MedKnow \\
\hline & 2011 & Q4 & MedKnow \\
\hline Ecology & 2011 & Q4 & soc \\
\hline \multirow{3}{*}{$\begin{array}{l}\text { Education, scientific } \\
\text { discipline }\end{array}$} & 2009 & Q4 & assoc \\
\hline & 2010 & Q4 & assoc \\
\hline & 2011 & Q4 & assoc \\
\hline \multirow{2}{*}{$\begin{array}{l}\text { Endocrinology and } \\
\text { metabolism }\end{array}$} & 2010 & Q4 & Springer India \\
\hline & 2011 & Q4 & Springer India \\
\hline Energy and fuel & 2011 & Q2 & Elsevier \\
\hline \multirow{3}{*}{$\begin{array}{l}\text { Engineering, } \\
\text { aerospace }\end{array}$} & 2009 & Q4 & center \\
\hline & 2010 & Q4 & center \\
\hline & 2011 & - & center \\
\hline \multirow{4}{*}{$\begin{array}{l}\text { Engineering, } \\
\text { chemical }\end{array}$} & 2008 & Q4 & NISCAIR \\
\hline & 2009 & Q4 & NISCAIR \\
\hline & 2010 & Q4 & NISCAIR \\
\hline & 2011 & Q4 & NISCAIR \\
\hline \multirow{3}{*}{$\begin{array}{l}\text { Engineering, } \\
\text { electrical and } \\
\text { electronic }\end{array}$} & 2009 & Q4, Q4 & MedKnow, inst \\
\hline & 2010 & Q4, Q4 & inst, MedKnow \\
\hline & 2011 & Q3, Q4 & inst, MedKnow \\
\hline \multirow{2}{*}{$\begin{array}{l}\text { Engineering, } \\
\text { mechanical }\end{array}$} & 2010 & Q4 & other \\
\hline & 2011 & Q4 & other \\
\hline \multirow[t]{4}{*}{$\begin{array}{l}\text { Engineering, } \\
\text { multidisciplinary }\end{array}$} & 2008 & Q4, Q4, Q4 & $\begin{array}{l}\text { Springer, } \\
\text { NISCAIR, } \\
\text { NISCAIR }\end{array}$ \\
\hline & 2009 & Q3, Q4, Q4 & $\begin{array}{l}\text { NISCAIR, } \\
\text { NISCAIR, IAS }\end{array}$ \\
\hline & 2010 & Q3, Q3, Q4 & $\begin{array}{l}\text { NISCAIR, IAS, } \\
\text { NISCAIR }\end{array}$ \\
\hline & 2011 & $\begin{array}{l}\text { Q3, Q4, Q4, } \\
\text { Q4, Q4 }\end{array}$ & $\begin{array}{l}\text { NISCAIR, Hindawi, } \\
\text { SPI, IAS, NISCAIR }\end{array}$ \\
\hline \multirow[t]{4}{*}{ Entomology } & 2008 & Q4 & other \\
\hline & 2009 & Q4 & other \\
\hline & 2010 & Q4 & other \\
\hline & 2011 & Q4 & $\mathrm{T}$ and $\mathrm{F}$ \\
\hline \multirow{4}{*}{$\begin{array}{l}\text { Environmental } \\
\text { sciences }\end{array}$} & 2008 & Q3, Q4 & other, soc \\
\hline & 2009 & Q4, Q4 & other, soc \\
\hline & 2010 & Q4 & other \\
\hline & 2011 & Q4, Q4, Q4 & $\begin{array}{l}\text { other, other, } \\
\text { Springer }\end{array}$ \\
\hline Fisheries & 2011 & Q4 & inst \\
\hline \multirow{4}{*}{$\begin{array}{l}\text { Food science and } \\
\text { technology }\end{array}$} & 2008 & Q4 & assoc \\
\hline & 2009 & Q4 & Springer India \\
\hline & 2010 & Q4 & Springer India \\
\hline & 2011 & Q4 & Springer India \\
\hline
\end{tabular}

Contd...
Table 1: Contd...

\begin{tabular}{|c|c|c|c|}
\hline Scientific field & Year & Category & Publisher \\
\hline \multirow{4}{*}{$\begin{array}{l}\text { Genetics and } \\
\text { heredity }\end{array}$} & 2008 & Q4 & Springer \\
\hline & 2009 & Q4 & IAS \\
\hline & 2010 & Q4, Q4 & IAS, KRE \\
\hline & 2011 & Q4, Q4 & IAS, KRE \\
\hline \multirow[t]{3}{*}{ Geology } & 2009 & Q4 & inst \\
\hline & 2010 & Q4 & inst \\
\hline & 2011 & Q4 & inst \\
\hline \multirow{4}{*}{$\begin{array}{l}\text { Geosciences, } \\
\text { multidisciplinary }\end{array}$} & 2008 & Q3, Q4 & Springer, soc \\
\hline & 2009 & Q4, Q4, Q4 & $\begin{array}{l}\text { IAS, Springer } \\
\text { India, other }\end{array}$ \\
\hline & 2010 & Q3, Q4, Q4 & $\begin{array}{l}\text { IAS, other, } \\
\text { Springer India }\end{array}$ \\
\hline & 2011 & Q4, Q4, Q4 & $\begin{array}{l}\text { IAS, other, } \\
\text { Springer India }\end{array}$ \\
\hline Hematology & 2011 & Q4 & Springer India \\
\hline \multirow[t]{3}{*}{ Horticulture } & 2009 & Q4 & soc \\
\hline & 2010 & Q4 & soc \\
\hline & 2011 & Q4 & soc \\
\hline \multirow[t]{4}{*}{ Immunology } & 2008 & Q4 & ICMR \\
\hline & 2009 & Q4 & ICMR \\
\hline & 2010 & Q4, Q4 & ICMR, MedKnow \\
\hline & 2011 & Q4, Q4 & ICMR, MedKnow \\
\hline Infectious diseases & 2011 & Q3 & ICMR \\
\hline \multirow{3}{*}{$\begin{array}{l}\text { Instruments and } \\
\text { instrumentation }\end{array}$} & 2009 & Q4 & soc \\
\hline & 2010 & Q4 & soc \\
\hline & 2011 & Q4 & soc \\
\hline \multirow{3}{*}{$\begin{array}{l}\text { Materials science, } \\
\text { ceramics }\end{array}$} & 2009 & Q4 & soc \\
\hline & 2010 & Q4 & soc \\
\hline & 2011 & Q3 & soc \\
\hline \multirow{4}{*}{$\begin{array}{l}\text { Materials science, } \\
\text { interdisciplinary }\end{array}$} & 2008 & Q3, Q4 & Springer, NISCAIR \\
\hline & 2009 & Q3, Q4 & IAS, NISCAIR \\
\hline & 2010 & Q3, Q4 & IAS, NISCAIR \\
\hline & 2011 & Q3, Q4 & IAS, NISCAIR \\
\hline \multirow[t]{4}{*}{ Mathematics } & 2008 & Q3, Q4 & Springer, INAS \\
\hline & 2009 & Q4, Q4, Q4 & other, IAS, SPI \\
\hline & 2010 & Q3, Q4, Q4 & other, assoc, IAS \\
\hline & 2011 & Q3, Q4, Q4 & Hindawi, SPI, IAS \\
\hline \multirow{3}{*}{$\begin{array}{l}\text { Mathematics, } \\
\text { applied }\end{array}$} & 2009 & Q3 & other \\
\hline & 2010 & Q2 & other \\
\hline & 2011 & Q2 & Hindawi \\
\hline \multirow[t]{2}{*}{ Mechanics } & 2010 & Q4 & other \\
\hline & 2011 & Q4 & other \\
\hline \multirow{2}{*}{$\begin{array}{l}\text { Medical laboratory } \\
\text { technology }\end{array}$} & 2010 & Q4 & MedKnow \\
\hline & 2011 & Q4 & MedKnow \\
\hline \multirow[t]{4}{*}{$\begin{array}{l}\text { Medicine, general } \\
\text { and internal }\end{array}$} & 2008 & Q2, Q2, Q3 & $\begin{array}{l}\text { ICMR, MedKnow, } \\
\text { AlIMS }\end{array}$ \\
\hline & 2009 & Q2, Q2, Q3 & $\begin{array}{l}\text { ICMR, MedKnow, } \\
\text { AlIMS }\end{array}$ \\
\hline & 2010 & Q2, Q2, Q3 & $\begin{array}{l}\text { ICMR, MedKnow, } \\
\text { AlIMS }\end{array}$ \\
\hline & 2011 & Q2, Q2, Q3 & $\begin{array}{l}\text { ICMR, MedKnow, } \\
\text { AllMS }\end{array}$ \\
\hline \multirow{2}{*}{$\begin{array}{l}\text { Medicine, research } \\
\text { and experimental }\end{array}$} & 2008 & Q3 & ICMR \\
\hline & 2009 & Q3 & ICMR \\
\hline
\end{tabular}

Contd... 
Table 1: Contd...

\begin{tabular}{|c|c|c|c|}
\hline Scientific field & Year & Category & Publisher \\
\hline & 2010 & Q3, Q4 & ICMR, SPI \\
\hline & 2011 & Q3 & ICMR \\
\hline \multirow{2}{*}{$\begin{array}{l}\text { Metallurgy and } \\
\text { metallurgical } \\
\text { engineering }\end{array}$} & 2010 & Q4 & Springer India \\
\hline & 2011 & Q4 & Springer India \\
\hline \multirow{3}{*}{$\begin{array}{l}\text { Meteorology and } \\
\text { atmospheric science }\end{array}$} & 2009 & Q4, Q4, Q4 & dept, other, assoc \\
\hline & 2010 & Q4, Q4, Q4 & other, assoc, dept \\
\hline & 2011 & Q4, Q4, Q4 & other, dept, assoc \\
\hline \multirow[t]{2}{*}{ Microbiology } & 2010 & Q4 & Springer \\
\hline & 2011 & Q4 & Springer \\
\hline \multirow[t]{4}{*}{$\begin{array}{l}\text { Multidisciplinary } \\
\text { sciences }\end{array}$} & 2008 & Q3, Q4, Q4 & $\begin{array}{l}\text { assoc, NASI, } \\
\text { center }\end{array}$ \\
\hline & 2009 & $\begin{array}{l}\text { Q2, Q3, } \\
\text { Q4, Q4 }\end{array}$ & $\begin{array}{l}\text { IAS, center, NASI, } \\
\text { NASI }\end{array}$ \\
\hline & 2010 & $\begin{array}{l}\text { Q2, Q3, } \\
\text { Q4, Q4 }\end{array}$ & $\begin{array}{l}\text { IAS, center, NASI, } \\
\text { NASI }\end{array}$ \\
\hline & 2011 & $\begin{array}{c}\text { Q2, Q3, Q4, } \\
\text { Q4, Q4 }\end{array}$ & $\begin{array}{l}\text { IAS, center, NASI, } \\
\text { KRE, NASI }\end{array}$ \\
\hline \multirow[t]{4}{*}{ Neurosciences } & 2008 & Q4 & MedKnow \\
\hline & 2009 & Q4 & MedKnow \\
\hline & 2010 & Q4 & MedKnow \\
\hline & 2011 & Q4 & MedKnow \\
\hline \multirow[t]{4}{*}{ Oceanography } & 2008 & Q4 & NISCAIR \\
\hline & 2009 & Q4 & NISCAIR \\
\hline & 2010 & Q4 & NISCAIR \\
\hline & 2011 & Q4 & NISCAIR \\
\hline \multirow[t]{2}{*}{ Oncology } & 2010 & Q4 & MedKnow \\
\hline & 2011 & Q4 & MedKnow \\
\hline \multirow[t]{2}{*}{ Ophthalmology } & 2010 & Q4 & soc \\
\hline & 2011 & Q3 & soc \\
\hline \multirow[t]{2}{*}{ Orthopedics } & 2010 & Q4 & MedKnow \\
\hline & 2011 & Q4 & MedKnow \\
\hline \multirow[t]{2}{*}{ Otorhinolaryngology } & 2010 & Q4 & Springer \\
\hline & 2011 & Q4 & Springer \\
\hline Parasitology & 2011 & Q4 & ICMR \\
\hline \multirow[t]{2}{*}{ Pathology } & 2010 & Q4 & MedKnow \\
\hline & 2011 & Q4 & MedKnow \\
\hline \multirow[t]{4}{*}{ Pediatrics } & 2008 & Q3, Q4 & other, AlIMS \\
\hline & 2009 & Q4, Q4 & other, AlIMS \\
\hline & 2010 & Q3, Q4 & $\begin{array}{l}\text { Springer India, } \\
\text { AllMS }\end{array}$ \\
\hline & 2011 & Q3, Q4 & $\begin{array}{l}\text { Springer India, } \\
\text { AllMS }\end{array}$ \\
\hline \multirow{3}{*}{$\begin{array}{l}\text { Pharmacology and } \\
\text { pharmacy }\end{array}$} & 2009 & Q4, Q4 & MedKnow, assoc \\
\hline & 2010 & Q4, Q4, Q4 & $\begin{array}{l}\text { MedKnow, } \\
\text { MedKnow, assoc }\end{array}$ \\
\hline & 2011 & Q4, Q4, Q4 & $\begin{array}{l}\text { MedKnow, } \\
\text { MedKnow, assoc }\end{array}$ \\
\hline \multirow[t]{3}{*}{ Physics, applied } & 2009 & Q4 & soc \\
\hline & 2010 & Q4 & soc \\
\hline & 2011 & Q4 & soc \\
\hline \multirow[t]{3}{*}{$\begin{array}{l}\text { Physics, } \\
\text { multidisciplinary }\end{array}$} & 2008 & Q4, Q4, Q4 & $\begin{array}{l}\text { NISCAIR, } \\
\text { Springer, assoc }\end{array}$ \\
\hline & 2009 & Q4, Q4, Q4 & $\begin{array}{l}\text { IAS, NISCAIR, } \\
\text { assoc }\end{array}$ \\
\hline & 2010 & Q3, Q3, Q4 & $\begin{array}{l}\text { IAS, NISCAIR, } \\
\text { assoc }\end{array}$ \\
\hline
\end{tabular}

Contd...
Table 1: Contd..

\begin{tabular}{|c|c|c|c|}
\hline Scientific field & Year & Category & Publisher \\
\hline & 2011 & Q3, Q3, Q4 & $\begin{array}{l}\text { NISCAIR, IAS, } \\
\text { assoc }\end{array}$ \\
\hline \multirow[t]{4}{*}{ Plant sciences } & 2008 & Q4 & soc \\
\hline & 2009 & $\begin{array}{l}\text { Q4, Q4, } \\
\text { Q4, Q4 }\end{array}$ & $\begin{array}{l}\text { soc, other, } \\
\text { NISCAIR, soc }\end{array}$ \\
\hline & 2010 & $\begin{array}{c}\text { Q4, Q4, Q4, } \\
\text { Q4, Q4 }\end{array}$ & $\begin{array}{l}\text { Springer India, } \\
\text { other, NISCAIR, } \\
\text { soc, soc }\end{array}$ \\
\hline & 2011 & $\begin{array}{l}\text { Q4, Q4, Q4, } \\
\text { Q4, Q4 }\end{array}$ & $\begin{array}{l}\text { Springer India, } \\
\text { NISCAIR, other, } \\
\text { soc, soc }\end{array}$ \\
\hline \multirow[t]{4}{*}{ Polymer science } & 2008 & Q4 & other \\
\hline & 2009 & Q4 & other \\
\hline & 2010 & Q4 & other \\
\hline & 2011 & Q4 & other \\
\hline \multirow[t]{4}{*}{ Remote sensing } & 2008 & Q4 & soc \\
\hline & 2009 & Q4 & soc \\
\hline & 2010 & - & - \\
\hline & 2011 & Q4 & Springer \\
\hline \multirow[t]{2}{*}{ Respiratory system } & 2010 & Q4 & MedKnow \\
\hline & 2011 & Q3 & soc \\
\hline \multirow{2}{*}{$\begin{array}{l}\text { Statistics and } \\
\text { probability }\end{array}$} & 2010 & Q4 & other \\
\hline & 2011 & Q4 & other \\
\hline \multirow[t]{2}{*}{ Surgery } & 2010 & Q4 & Springer India \\
\hline & 2011 & Q4 & Springer India \\
\hline \multirow[t]{3}{*}{ Telecommunication } & 2009 & Q4, Q4 & MedKnow, inst \\
\hline & 2010 & Q4, Q4 & inst, MedKnow \\
\hline & 2011 & Q3, Q4 & inst, MedKnow \\
\hline Tropical medicine & 2011 & Q4 & ICMR \\
\hline \multirow[t]{4}{*}{ Veterinary sciences } & 2008 & Q4, Q4 & other, other \\
\hline & 2009 & Q4, Q4 & other, other \\
\hline & 2010 & Q4, Q4 & other, other \\
\hline & 2011 & Q4 & other \\
\hline \multirow[t]{2}{*}{ Virology } & 2009 & Q4 & soc \\
\hline & 2010 & Q4 & soc \\
\hline \multirow[t]{3}{*}{ Water resources } & 2009 & Q4 & other \\
\hline & 2010 & Q4 & other \\
\hline & 2011 & Q4 & other \\
\hline
\end{tabular}

* Categories of journals in a scientific field are listed in decreasing order and corresponding publishers appear successively in that order. ICMR = Indian Council of Medical Research, $\mathrm{soc}=$ Societies, NISCAIR = National Institute of Science Communication and Information Resources, inst $=$ Institutes

Depending on the number of citations received by the papers published in a given journal in 2-and 5-year citation windows, IF2 and IF5 of the journal are usually different. However, the subject category $\mathrm{Q}$ of a journal belonging to a scientific area in the Thomson Reuters' JCR databases is determined on the basis of the distribution of the IF2s of all of the journals belonging to the scientific area in the percentile ranges $100-75 \%, 75-50 \%, 50-25 \%$, and $25-0 \%$, defined as quartiles Q1, Q2, Q3, and Q4, respectively, from the topmost subject category Q1 to the lowest subject category Q4. In cases when the scope of a journal 
Table 2: Participation of different publishers of journals in India

\begin{tabular}{lcccc}
\hline Publisher & \multicolumn{4}{c}{$N_{\text {jrnl }}$} \\
\cline { 2 - 5 } & 2008 & 2009 & 2010 & 2012 \\
\hline Springer India & - & 2 & 7 & 8 \\
Springer & 9 & - & 2 & 3 \\
Taylor and Francis (T and F) & - & - & - & 2 \\
Elsevier & - & - & - & 1 \\
MedKnow & 2 & 5 & 12 & 12 \\
Hindawi & - & - & - & 2 \\
Indian Academy of Sciences (IAS) & - & 10 & 10 & 10 \\
National Institute of Science Communication & 9 & 10 & 11 & 11 \\
and Information Resources (NISCAIR) & & & & \\
Indian Council of Agricultural & 2 & 2 & 2 & 2 \\
Research (ICAR) & & & & \\
All India Institute of Medical Sciences (AIIMS) & 2 & 2 & 2 & 2 \\
Indian Council of Medical Research (ICMR) & 1 & 1 & 1 & 2 \\
Scientific Publishers, India (SPI) & 2 & 1 & 3 & 2 \\
National Academy of Sciences of & 1 & 2 & 3 & 3 \\
India (NASI) & & & & \\
Kamla-Raj Enterprises (KRE) & - & - & 1 & 2 \\
Societies (soc) & 3 & 8 & 10 & 11 \\
Associations (assoc) & 3 & 4 & 5 & 4 \\
Research Institutes/Centers/Departments & 1 & 3 & 7 & 7 \\
(inst, center, dept) & & & & \\
Others (other) & 10 & 15 & 17 & 16 \\
Sum & 45 & 68 & 94 & 100 \\
\hline
\end{tabular}

Table 3: Numbers $\boldsymbol{N}_{\text {jrnl }}$ of journals with IF2s, IF5 and different quartiles of categories $\mathbf{Q}$

\begin{tabular}{|c|c|c|c|c|c|c|c|c|}
\hline \multirow[t]{2}{*}{ Year } & \multicolumn{3}{|c|}{ Journals } & \multicolumn{5}{|c|}{ Categories (\%) } \\
\hline & $N_{\mathrm{jrml}}$ & IF2 & IF5 & Q1 & Q2 & Q3 & Q4 & $\Sigma Q$ \\
\hline 2008 & 45 & 45 & 40 & - & $3(5.8)$ & $10(19.2)$ & $39(75.0)$ & 52 \\
\hline 2009 & 68 & 68 & 41 & - & $4(4.8)$ & $11(13.1)$ & $69(82.1)$ & 84 \\
\hline 2010 & 94 & 92 & 45 & - & $6(7.2)$ & $16(14.4)$ & $89(80.2)$ & 111 \\
\hline 2011 & 100 & 99 & 47 & - & $8(6.6)$ & $22(18.0)$ & $92(75.4)$ & 122 \\
\hline
\end{tabular}

covers more than one research area, it is assigned different Qs representing the ranking of the journal in the list of journals belonging to each area.

\section{PUBLISHING TRENDS OF JOURNALS}

It may be seen from Table 1 that during the 4-year period multidisciplinary research fields like agriculture, chemistry, engineering, geosciences and general sciences (multidisciplinary sciences), dairy and animal sciencesrelated agriculture, agronomy, biology, biotechnology and applied microbiology, and plant sciences have witnessed a steady increase in the number of journals. In other fields such as mathematics, pharmacology and pharmacy, and general and internal medicine there is an insignificant increase in the number of journals, whereas the number of journals in other fields has remained practically unchanged. In 2010 and 2011, new journals have been initiated, inter alia, in the fields of medical and medicinal sciences (e.g., in anatomy and morphology, cardiology and cardiovascular system, clinical neurology, hematology, medical laboratory technology, oncology, parasitology, and surgery), ecology, energy and fuel, and biotechnology and applied microbiology.

From Tables 1 and 2, it may be noted that in 2008 Springer and National Institute of Science Communication combined with Council of Scientific and Industrial Research (amalgamated later as National Institute of Science Communication and Information Resources (NISCAIR)) were the main publishers with nine journals each. However, in 2009 most of the journals published by Springer in the previous year and the journal "Current Science India," one of the topmost journals in multidisciplinary sciences, published previously by Current Science Association were acquired by Indian Academy of Sciences (IAS). In 2010 and 2011 some journals previously published by individual publishers were taken over mainly by Springer India, Taylor and Francis, and Hindawi.

Since 2008, Springer/Springer India, MedKnow, IAS, and NISCAIR have emerged as the main publishers of scientific journals in India, which publish about $40 \%$ of the journals. Individual societies, associations, research institutes, centers, and departments publish over $40 \%$ of the journals [Table 2]. There are also other publishers, usually with one journal listed in the JCR list in a given year, which publish the remaining $20 \%$ of the journals. Although multinational publishers like Elsevier as well as Taylor and Francis are also present since 2011, their contribution to the publication of journals is relatively small.

The number of Indian journals listed in the JCR reports has increased steadily from 45 in 2008 to 100 in 2011, showing an increase by a factor of 2.2 [Table 3]. However, the number of journals with IF5 has increased by a factor of 1.18 only. This means that most of the journals included in the JCR in 2010 and 2011 are new. The sum of the categories of the journals is higher by about $20 \%$ than their number in a given year because some journals are categorized in more than one JCR category. In all of the years considered here, there is no journal in category Q1 but the number of journals increases successively in categories Q2, Q3, and Q4 [Table 3]. The number of journals in a particular category also increases with the increasing number of journals included in the JCR list in 
successive years but the fractional participation of journals belonging to different quartiles does not change drastically in different years.

Top 20 and bottom 20 Indian journals indexed in JCR 2011, together with their IF2 with and without selfcitations and IF5, are compared in Table 4 with the journals indexed in 2009. The following features may be seen from this table:
1. In contrast to $55 \%$ of the top journals, only $15 \%$ of the bottom journals have their IF5. This means that many of the journals were included in the JCR indexing system only recently but their ranking in the IF2 order strongly depends on the publication duration. It is also interesting to note that $70 \%$ of the top journals were published by MedKnow, IAS, NISCAIR, and ICMR, which were the dominating publishers in 2011. However, most of the bottom journals were published

Table 4: Top 20 and bottom 20 Indian journals in 2011 compared with same journals in $2009 \S$

\begin{tabular}{|c|c|c|c|c|c|}
\hline No & Journal & IF2 & IF5 & IF2 ${ }_{\text {nsc }}$ & Publisher \\
\hline 1. & B Astron Soc India & $2.722(0.310)$ & & $2.500(0.310)$ & soc \\
\hline 2. & Indian J Med Res & $1.837(1.516)$ & $2.193(1.941)$ & $1.724(1.298)$ & ICMR \\
\hline 3. & J Biosciences & $1.648(1.956)$ & $2.218(1.876)$ & $1.517(1.923)$ & IAS \\
\hline 4. & Energy Sustain Dev & 1.625 & & 1.413 & Elsevier \\
\hline 5. & Ann Thorac Med & 1.617 & & 1.400 & soc \\
\hline 6. & Indian J Exp Biol & $1.295(0.550)$ & 1.099 & $1.212(0.520)$ & NISCAIR \\
\hline 7. & J Postgrad Med & $1.263(1.389)$ & 1.586 & $1.222(1.284)$ & MedKnow \\
\hline 8. & J Chem Sci & $1.177(0.993)$ & $1.241(1.206)$ & $1.095(0.954)$ & IAS \\
\hline 9. & J Vector Dis & 1.177 & & 1.094 & ICMR \\
\hline 10. & Pharmacogn Mag & 1.159 & & 0.857 & other \\
\hline 11. & Indian J Biochem Bio & $1.142(0.574)$ & $0.911(0.547)$ & $1.110(0.508)$ & NISCAIR \\
\hline 12. & J Genet & $1.086(0.762)$ & $1.238(0.738)$ & $1.057(0.714)$ & IAS \\
\hline 13. & Indian Pediatr & $1.048(0.962)$ & 1.052 & $0.912(0.793)$ & Springer India \\
\hline 14. & Indian J Ophthalmol & 1.019 & & 0.757 & soc \\
\hline 15. & Indian J Med Microbi & 0.988 & & 0.870 & MedKnow \\
\hline 16. & Indian J Dermatol Ve & $0.979(0.976)$ & & $0.878(0.820)$ & MedKnow \\
\hline 17. & Neurol India & $0.956(0.796)$ & $0.968(1.106)$ & $0.968(0.707)$ & MedKnow \\
\hline 18. & Curr Sci India & $0.935(0.782)$ & $1.110(1.110)$ & $0.782(0.645)$ & IAS \\
\hline 19. & Ann Indian Acad Neur & 0.928 & & 0.681 & MedKnow \\
\hline 20. & Indian J Chem A & $0.891(0.617)$ & $0.710(0.634)$ & $0.776(0.470)$ & NISCAIR \\
\hline 81. & P Indian AS Math Sci & $0.165(0.382)$ & $0.314(0.460)$ & $0.165(0.348)$ & IAS \\
\hline 82. & Res J Biotechnol & $0.143(0.174)$ & & $0.114(0.151)$ & other \\
\hline 83. & Indian J Anim Sci & $0.122(0.137)$ & $0.130(0.146)$ & $0.064(0.054)$ & ICAR \\
\hline 84. & J Agrometeorol & $0.114(0.065)$ & & $0.057(0.009)$ & assoc \\
\hline 85. & Indian J Pharm Educ & $0.106(0.150)$ & & $0.096(0.140)$ & assoc \\
\hline 86. & Legume Res & 0.088 & & 0.029 & center \\
\hline 87. & Indian J Surg & 0.081 & & 0.048 & Springer India \\
\hline 88. & J Pure Appl Microbio & 0.065 & & 0.047 & other \\
\hline 89. & J Camel Pract Res & $0.061(0.223)$ & $0.123(0.247)$ & $0.030(0.074)$ & other \\
\hline 90. & Indian J Hematol Bio & 0.056 & & 0.037 & Springer India \\
\hline 91. & J Anat Soc India & 0.056 & & 0.056 & soc \\
\hline 92. & Res Crop & 0.050 & & 0.036 & center \\
\hline 93. & P Natl A Sci India A & $0.044(0.140)$ & & $0.044(0.121)$ & NASI \\
\hline 94. & Indian J Fish & 0.040 & & 0.024 & inst \\
\hline 95. & Vegetos & $0.039(0.030)$ & & $0.039(0.015)$ & soc \\
\hline 96. & Indian J Otolaryngol & 0.033 & & 0.029 & Springer \\
\hline 97. & Indian J Anim Res & 0.020 & & 0.020 & center \\
\hline 98. & P Natl A Sci India B & 0.019 & & 0.009 & NASI \\
\hline 99. & Int J Agric Stat Sci & $0.013(0.092)$ & & $0.000(0.000)$ & other \\
\hline 100. & J Spacecr Technol & $0.000(0.034)$ & & $0.000(0.034)$ & other \\
\hline
\end{tabular}

${ }^{\S}$ Values without parentheses and in parentheses given in IF2, IF5 and IF2 ${ }_{\text {nsw }}$ columns are for 2011 and 2009, respectively 
by scientific societies, associations, centers, and other individual publishers

2. With their increasing publication duration, the values of IF 2 and IF5 of the top journals increase, whereas those of the bottom journals decrease. This observation is associated with the process of dissemination of contents of the journals and the difference in their scientific field. In the dissemination process established publishers have an advantage over small, individual publishers. However, the dissemination process of the journals can be different even among the dominating publishers. For example, the increase in the IF2 of the top journals from 2009 to 2011 is significantly higher for NISCAIR than that for MedKnow, which started its large-scale journal publication activities in 2009 [Table 1]. The situation in the case of journals published by Springer India, which also started its publication activities in 2009, is similar to that of MedKnow

3. A majority of the top journals belong to medical and medicinal sciences. Other top journals belong to astronomy and astrophysics (journal 1), energy and fuel (journal 4), biology (journal 6), multidisciplinary chemistry (journals 8 and 20), and multidisciplinary sciences (journal 18)

4. The IF $2_{\text {nsw }}$ for most of the journals differ no more than 30\% from their corresponding IF2. This means that the editorial policy of most of the journals is to discourage journal self-citations to improve their IFs.

\section{JOURNAL IF2 AND NONSELF-CITATION OCTILES}

From the data of IF2 and IF2 ${ }_{\text {nsc }}$ for the journals compiled from the JRC files the parameter $P=\mathrm{IF} 2_{\text {nsc }} / \mathrm{IF} 2$ was calculated. The parameter $P$ is a measure of the nonselfcitations (NSCs) of a journal. The higher the value of $P$, the lower is the contribution of self-citations to its IF2. The distribution of the values of the parameter $P$ of different journals as a function of their corresponding IF2 is shown in Figure 1 for the 4 years. It may be noted from Figure 1 that the value of IF 2 of the top journal increases in successive years from 1.884 in 2008 to 2.722 in 2011 and is directly connected with the number $N$ of the journals in different years.

In order to analyze the distribution of the parameter $P$ of journals as a function of their IF2, the entire range

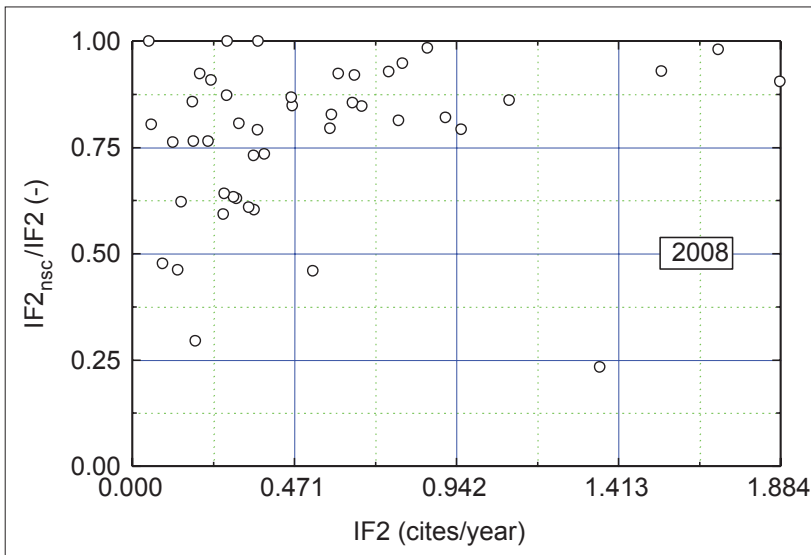

(a)

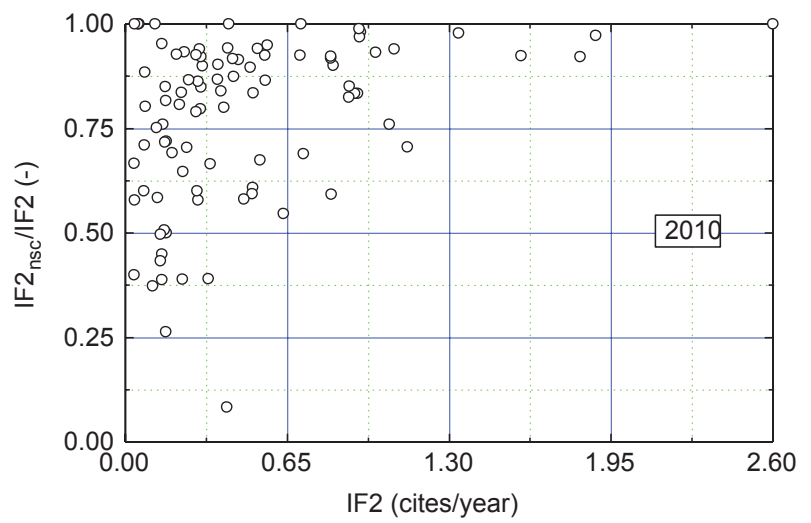

(c)

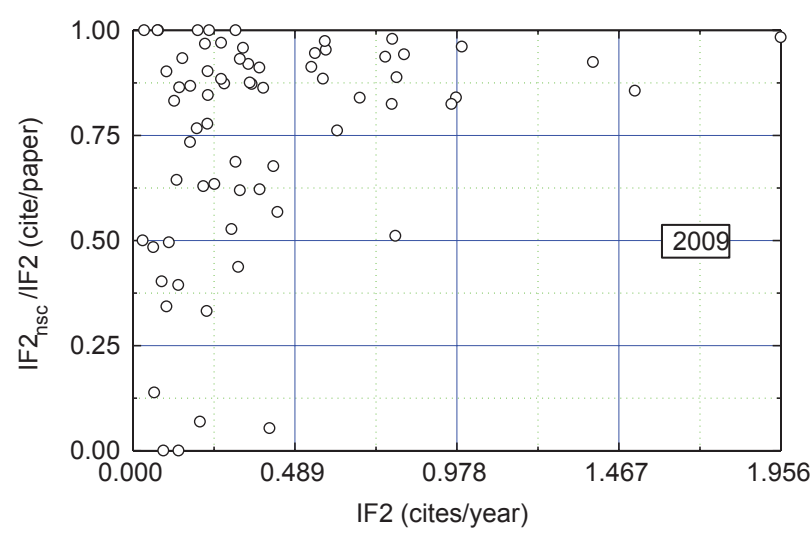

(b)

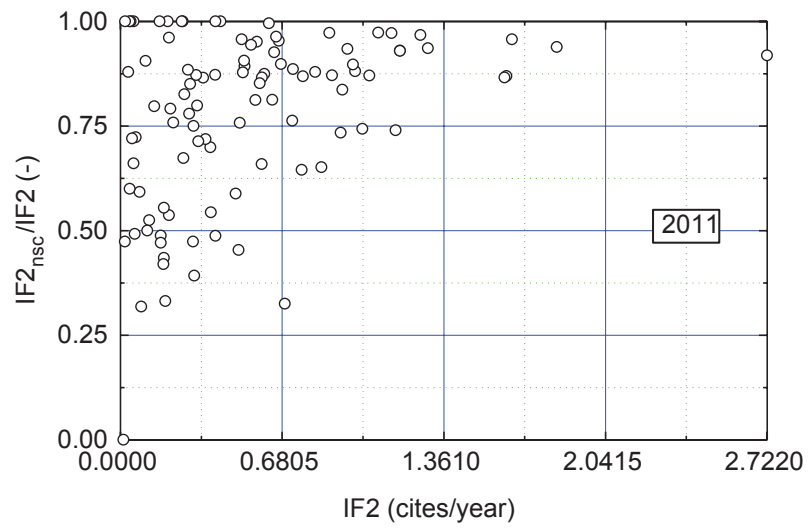

(d)

Figure 1: Distribution of ratio P of journals of various IF2 in different years: (a) 2008, (b) 2009, (c) 2010, and (d) 2011 
$1>P>0$ was divided into eight groups, called hereafter as NSC octiles, in the order of decreasing $P$. This means that the lowest NSCs correspond to $P$ close to unity, whereas the highest NSCs correspond to $P$ close to zero. Obviously, NSC groups 1 and 8 correspond to $1>P>0.875$ and $0.125>P>0$, respectively, whereas other NSC groups 2-7 lie between the above groups. Similarly, considering the highest IF $2_{\text {max }}$ of IF2 of the top journal in a particular year as a normalization factor, the fraction $F$, defined as $F=\mathrm{IF} 2 / \mathrm{IF} 2_{\max }$, was calculated and the distribution of the values of the fraction $F$ for different crystals was split into eight groups $F$ on the basis of octiles in the order of increasing IF2. Obviously, in this case journals with IF2-based octiles 1 and 8 correspond to $0<F<0.125$ and $0.875<F<1$, respectively, but the other IF2-based octiles 2-7 lie between octiles 1 and 8 . This type of division of the data of $P$ of the journals corresponding to IF2 on the basis of octiles is illustrated in Figure 1.

It should be noted that the concept of octiles used in this paper is similar to that of quartiles used in Thomson Reuters' JCR databases for the categorization of journals belonging to different scientific disciplines. In the present case, the reference is the country of origin of journals (e.g., India here) instead of a scientific discipline and successive pairs of octiles form quartiles. For example, our NSC octile groups 1 and 2, 3 and 4,5 and 6, and 7 and 8 may be considered as NSC quartiles 1, 2, 3, and 4, respectively. Similarly, our IF2-based octiles 1 and 2, 3 and 4, 5 and 6, and 7 and 8 are IF2-based quartiles 4, 3, 2, and 1, respectively.

From the plots of the parameter $P$ against IF2 for different journals the numbers of the parameter $P$ in different NSC octiles and the numbers of the fraction $F$ in different

IF2-based octiles were counted. The results are given in Table 5. Using the values of $P$ and $F$ in different octiles and the number $N$ of journals published in a year the frequencies $f_{P}=P / N$ and $f_{F}=F / N$ of participation of NSC parameter $P$ and IF2 fraction $F$ in different NSC octiles and IF2-based octiles, respectively, were calculated. The data of $f_{P}$ against NSC octiles $P$ and $f_{F}$ against IF2-based octiles $F$ are presented in the histograms of Figure $2 \mathrm{a}$ and $\mathrm{b}$, respectively. The histograms of Figure 2 suggest that $f_{P}$ decreases with increasing $P$, whereas $f_{F}$ increases with increasing $F$ practically exponentially. The dependences of $\ln f_{P}$ on $P$ and $\ln f_{F}$ on $F$ are shown in Figure $3 a$ and b, respectively. In the figures, the linear plots are drawn for the data of 2011.

With the exception of $\ln f_{P}$ data corresponding to octile 8 of NSC parameter $P$ for 2009 and $\ln f_{F}$ data corresponding to $F$ octiles 7 and 8 for 2008 and 2009, the entire data follow the linear dependence described by the usual exponential relation

$f=f_{0} \exp (-a x)$,

where $f$ denotes $f_{P}$ or $f_{F}, x$ denotes $P$ or $F, a$ is a parameter characterizing a particular dependence, whereas $f_{0}$ is a

\begin{tabular}{|c|c|c|c|c|c|c|c|c|c|c|}
\hline Year & Feature & 1 & 2 & 3 & 4 & 5 & 6 & 7 & 8 & Sum \\
\hline \multirow[t]{2}{*}{2008} & $\mathrm{NSC}(P)$ & 13 & 19 & 4 & 4 & 3 & 1 & 1 & 1 & 45 \\
\hline & IF2 $(F)$ & 12 & 15 & 7 & 5 & 2 & 1 & 1 & 2 & 45 \\
\hline \multirow[t]{2}{*}{2009} & $\mathrm{NSC}(P)$ & 29 & 15 & 6 & 5 & 6 & 2 & 1 & 4 & 68 \\
\hline & IF2 $(F)$ & 29 & 20 & 7 & 7 & 2 & 1 & 1 & 1 & 68 \\
\hline \multirow[t]{2}{*}{2010} & $\mathrm{NSC}(P)$ & 36 & 23 & 11 & 11 & 8 & 2 & 0 & 1 & 92 \\
\hline & $\mathrm{IF} 2(F)$ & 46 & 23 & 14 & 4 & 2 & 2 & 0 & 1 & 92 \\
\hline \multirow[t]{2}{*}{2011} & $\mathrm{NSC}(P)$ & 40 & 25 & 12 & 8 & 10 & 3 & 0 & 1 & 99 \\
\hline & IF2 (F) & 43 & 28 & 15 & 8 & 3 & 1 & 0 & 1 & 99 \\
\hline
\end{tabular}

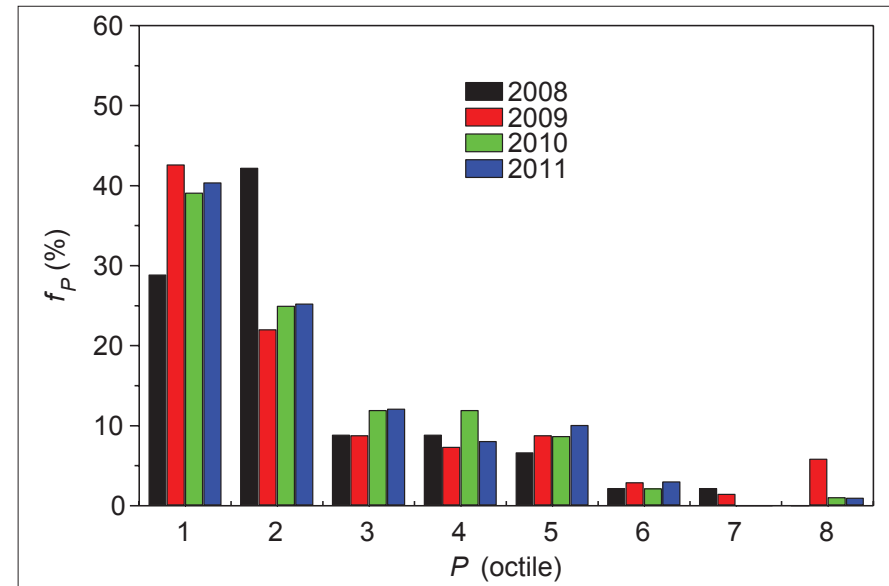

(a)

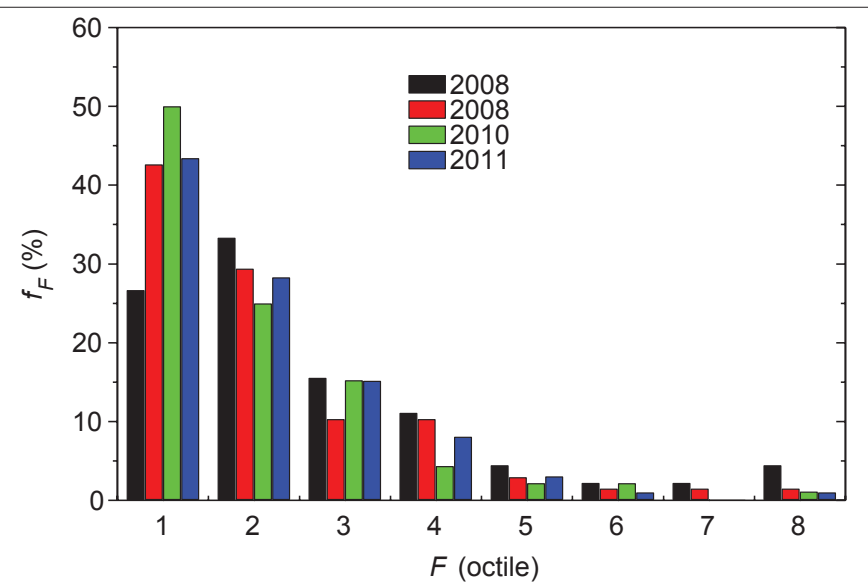

(b)

Figure 2: (a) Histogram of frequency $f_{P}$ of distribution of journals of different nonself-citation octiles $P$ for 4 years. (b) Histogram of frequency $f_{F}$ of distribution of journals of different IF2 octiles $F$ for 4 years 


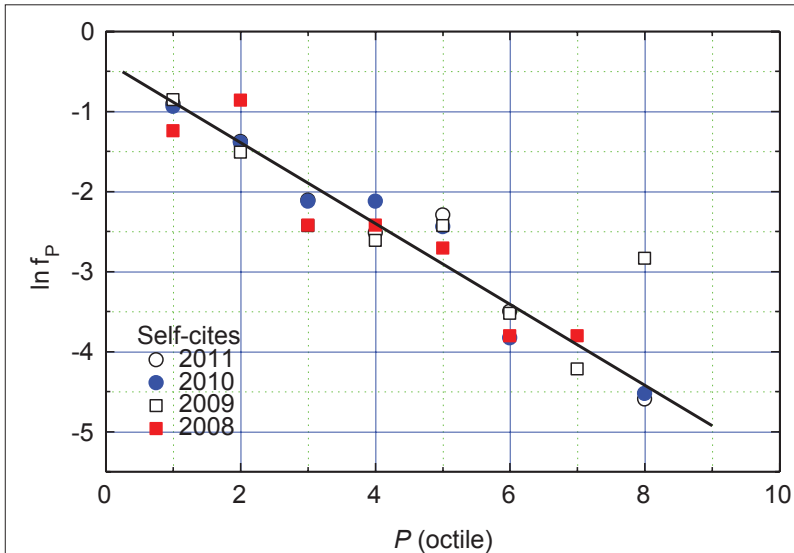

(a)

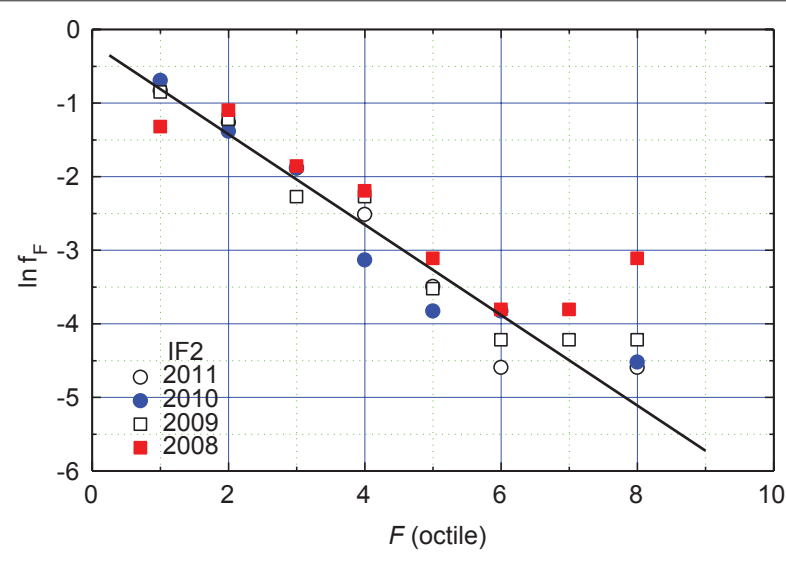

(b)

Figure 3: Dependence of (a) $\ln f_{P}$ on nonself-citation octile $P$ and (b) $\ln f_{F}$ on IF2 octile $F$ of journals.

normalizing frequency corresponding to $x=0$ and is characteristic of the $f_{P}(P)$ and $f_{F}(F)$ data. The values of the constants are listed in Table 6.

For sufficiently large values of $x$, the relation between the number $y$ of items and the rank $x$ of the successive sources generating the items is described. ${ }^{[9-13]}$

$y=y_{0} \exp \left[-\left(\frac{x}{x_{0}}\right)^{\beta}\right]$

where $y_{0}$ denotes the number of items generated by the maximally active source, and $\beta$ and $n_{0}$ are empirical constants. For real distributions of a variety of data sets of natural and economic phenomena such as radio and light emissions from galaxies, oilfield reserve sizes, agglomeration sizes, country population sizes, daily currency exchange variations, and citations of authors, it is found that the constant $\beta \leq 1$. .9-11,13] $^{-13}$ The case when $\beta=1$ corresponds to the usual exponential distribution (1) with the constant $a=1 / x_{0}$. However, it is observed that stretched exponential relation (1) does not describe the data in the entire range of $x$ and deviations often occur in the range of very low and high $x$. The exceptions occurring in octiles of high self-citation and high IF2 journals in Figure 2a and $\mathrm{b}$ may be explained in this way.

It should be mentioned that, apart from the exponential dependence, several other mathematical functions have been reported in the literature to describe the above type of $y(x)$ data. These functions are given by Sangwal. ${ }^{[12]}$

\section{RELATIONSHIP BETWEEN IF2 AND IF5}

Figure 4 shows the dependence of IF2 of journals published in India for 2008-2011 against their corresponding IF5,

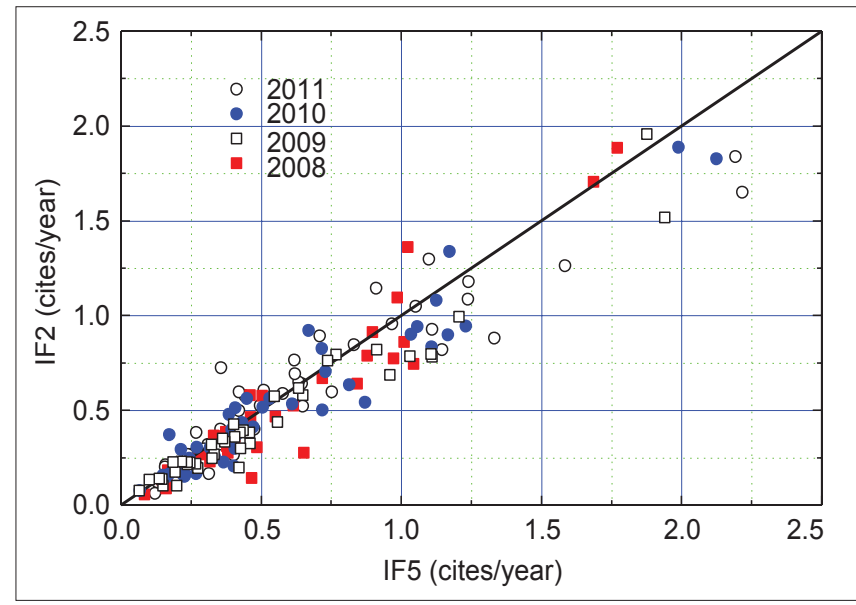

Figure 4: Relationship between IF2 and IF5 of journals

Table 6: Values of constants $f_{0}$ and a for $f_{P}(P)$ and $f_{F}(F)$ data

\begin{tabular}{lcccc}
\hline Data & Figure & $\operatorname{Inf}_{0}$ & $\boldsymbol{f}_{\mathbf{0}}$ & $-\mathbf{a}$ \\
\hline$f_{P}(P)$ & $3 \mathrm{a}$ & $-0.377 \pm 0.245$ & 0.69 & $0.505 \pm 0.052$ \\
$f_{F}(F)$ & $3 \mathrm{~b}$ & $-0.196 \pm 0.338$ & 0.82 & $0.614 \pm 0.072$ \\
\hline
\end{tabular}

whereas the linear plot represents a slope of unity when IF2 = IF5 for different journals. As seen from this figure, the maximum value of IF5 increases with an increase in the total number of the journals with IF5. This observation is similar to that of an increase in the value of IF2 with an increase in the number of journals published in successive years.

In Figure 4, a majority of the data points lie below the linear plot, implying that IF5 > IF2 for most of the journals. In fact, as seen from Table 7, IF5 > IF2 for most of the journals but the proportion of journals where IF5 $>$ IF2 varies enormously in different years. For example, IF5 > IF2 for about 75\% journals in 2009 and about 51\% 
Table 7: Number of Indian journals with IF2, IF5 $>$ IF2 and IF5 $<$ IF2

\begin{tabular}{ccccc}
\hline Year & $\boldsymbol{N}_{\text {IF5 }}$ & IF5>IF2 & IF5<IF2 & IF2=IF5 \\
\hline 2008 & 40 & 26 & 13 & 1 \\
2009 & 41 & 31 & 9 & 1 \\
2010 & 45 & 28 & 16 & 1 \\
2011 & 47 & 24 & 23 & 0 \\
\hline
\end{tabular}

journals in 2011. Similar observations have been reported previously in the literature. ${ }^{[14,15]}$ From a comparison of IF2 and IF5 of top 20 international journals from Thomson Reuters' 2008 JCR database, Companario ${ }^{[14]}$ found that IF5 $>$ IF2 for most journals but the IF5 < IF2 for about a quarter of them.

Using the scientific publication output of Norwey, Aksnes and Sivertsen ${ }^{[16]}$ found that: (1) there are large annual variations in the influence of highly cited papers on the average citation rate of the subfields and (2) the average citation rates of papers in major subfields are strongly determined by one or only a few highly cited papers. These observations are associated with the highly skewed distribution of citations of papers published in journals. Therefore, IF 2 of a journal is increased primarily by the high-tank papers receiving high citations. ${ }^{[17,18]}$ In view of this skewness of citation distribution of papers in journals, a huge number of citations received by an individual paper published in a journal can have a dramatic effect on its IF2. ${ }^{[18]}$ The increase or decrease in the IF2 of journals observed in the present study may be attributed to relatively high or low citations received by high-rank papers published in the latest 2 years than in the previous years.

\section{CONCLUSIONS}

The main findings of the study are the following:

1. Since 2008, Springer/Springer India, MedKnow, IAS, and NISCAIR have emerged as the main publishers of scientific journals in India, which publish about $40 \%$ of the journals. Individual societies, associations, research institutes, centers, and departments publish over $40 \%$ of the journals. There are also other publishers, usually with one journal listed in the JCR list in a given year, which publish about $20 \%$ of the journals. Among the leading publishers, MedKnow and Springer/Springer India have consolidated their positions in 2010 and 2011

2. A majority of the top Indian journals belong to medical and medicinal sciences and are published by dominating publishers like MedKnow, IAS, NISCAIR, and ICMR
3. Comparison of the IF2 with and without self-citations and IF5 of top 20 and bottom 20 Indian journals indexed in JCR 2011 with those of the journals indexed in 2009 revealed that $55 \%$ of the top journals and $15 \%$ of the bottom journals have their IF5. This means that many of the journals were included in the JCR indexing system only recently but their ranking in the IF2 order strongly depends on the publication duration. Moreover, $70 \%$ of the top journals were published by MedKnow, IAS, NISCAIR, and ICMR, which were the dominating publishers in 2011, whereas most of the bottom journals were published by scientific societies, associations, centers, and other individual publishers

4. With their increasing publication duration, the values of IF 2 and IF5 of the top journals increase, whereas those of the bottom journals decrease. This observation is associated with the process of dissemination of contents of the journals and the difference in their scientific field. In the dissemination process, established publishers have an advantage over small, individual publishers

5. The frequency $f_{P}=P / N$ of distribution of NSC octiles $P$ $=\mathrm{IF} 2_{\text {nsc }} / \mathrm{IF} 2$ and the frequence $f_{F}=F / N$ of IF2 octiles $F$ for different years, where $\mathrm{IF}_{\text {nsc }}$ is the 2-year impact factor of a journal without NSCs and Nis the number of journals with IF2 in a given year, follow exponential dependence

6. IF5 $>$ IF2 for most of the journals but the proportion of journals where IF5 > IF2 varies enormously in different years.

\section{ACKNOWLEDGEMENT}

The author expresses his gratitude to Dr. Kazimierz Wójcik for his assistance during collection of bibliometric data from the Journal Citation Reports.

\section{REFERENCES}

1. Garfield E. Do French scientists who publish outside of France and/or in English do better research? Curr Contents 1978;22:5-10.

2. Gonzalez-Alcaide G, Valderrama-Zurian JC, Aleixandre-Benavent $R$. The impact factor in non-English-speaking countries. Scientometrics 2012;92:297-311.

3. Liang L, Rousseau R, Zhong Z. Non-English journals and papers in physics and chemistry: Bias in citations? Scientometrics 2013, 95:333-50.

4. Mueller PS, Murali NS, Cha SS, Erwin PF, Ghosh AK. The association between impact factors and language of general internal medicine journals. Swiss Med Wkly 2006;136:441-3.

5. Poomkottayil D, Bornstein MM, Sendi P. Lost in translation: The impact of publication language on citation frequency in the scientific dental literature. Swiss Med Wkly 2011;141:w13148.

6. Sangwal K. On the relationship between citations of publication 
output and Hirsch index $\mathrm{h}$ of authors: Conceptualization of tapered Hirsch index $h_{T}$, circular citation area radius $R$ and citation acceleration a. Scientometrics 2012;93:987-1004.

7. van Raan $T$, van Leeuwen $T$, Visser M. Non-English papers decrease ranking. Nature 2011;469:34.

8. Sangwal K. Some citation-related characteristics of scientific journals published in individual countries. Scientometrics 2013 (in press).

9. Hirsch JE. An index to quantify an individual's scientific research output. Proc Natl Acad Sci U S A 2005;102:16569-72.

10. Leherrere J, Sornette D. Stretched exponential distributions in nature and economy "fat tails" with characteristic scales. Eur Phys J B 1998;8:535-9.

11. Redner $\mathrm{S}$. How popular is your paper? An empirical study of the citation distribution. Eur Phys J B 1998;4:131-4.

12. Sangwal K. Comparison of different mathematical functions for the analysis of citation distribution of papers of individual authors. J Informetr 2013, 7: 36-49.

13. Wallace ML, Lariviere $\mathrm{V}$, Gingras $Y$. Modeling a century of citation distributions. J Informetr 2009;3:296-303.

14. Campanario JM. Empirical study of journal impact factor obtained using the classical two-year citation window versus a five-year ciation window. Scientometrics 2011;87:189-204.

15. Rousseau R, Jin B, Yang N. Observations concerning the two- and three-year synchronous impact factor, based on Chinese science database. J Doc 2001;57:349-57.

16. Aksnes DW, Sivertsen G. The effect of highly cited papers on national citation indicators. Scientometrics 2004;59:213-24.

17. Vinkler P. The Garfield impact factor, one of the fundamental indicators in scientometrics. Scientometrics 2012;92: 471-83.

18. Moed HF, Colledge L, Reedijk J, Moya-Anegon F, Guerrero-Bote V, Plume A, et al. Citation-based metrics are appropriate tools in journal assessment provided that they are accurate and used in an informed way. Scientometrics 2012;92:367-76.

How to cite this article: Sangwal K. Recent growth of scientific journals published in India: Some publishing and citation-related characteristics. J Sci Res 2013;2:59-69.

Source of Support: Nil, Conflict of Interest: None declared 